Discussion Paper No. 573

\title{
WHY ARE THE WAGES OF JOB STAYERS PROCYCLICAL?
}

\author{
Donggyun Shin \\ and \\ Kwanho Shin
}

March 2003

The Institute of Social and Economic Research

Osaka University

6-1 Mihogaoka, Ibaraki, Osaka 567-0047, Japan 


\title{
Why Are The Wages of Job Stayers Procyclical?
}

\author{
Donggyun Shin* and Kwanho Shin**
}

January 2003

This paper has greatly benefited from thorough readings and comments made by John DiNardo and Gary Solon. The authors also thank seminar participants at the Korean Labor Economic Workshop and the Korean Macroeconomic Workshop for helpful discussions. Part of this paper was written while Kwanho Shin was affiliated as a visiting foreign scholar with Institute of Social and Economic Research, Osaka University. All errors and omissions are ours.

* Department of Economics, Hanyang University, 17 Hangdang-Dong, Sungdong-Gu, Seoul, Korea, dgshin@ hangyang.ac.kr

** Department of Economics, Korea University, 1-5 Anam-Dong, Sungbuk-Gu, Seoul, Korea khshin@korea.ac.kr 


\begin{abstract}
This paper explains how real wages are procyclical for those who stay with the same employer. On the basis of the Panel Study of Income Dynamics data for the period of 1974-75 to 1990-91, we find that the substantial wage procyclicality among job stayers is mostly accounted for by great wage adjustments during the period when the unemployment rate reaches a historical minimum level from the start of the employee's current job. This finding explains how the real wages of job stayers behave asymmetrically over the cycle and more importantly how the evidence of stayers' great wage procyclicality accords with the theoretical prediction of implicit contracts that stresses costless mobility.
\end{abstract}

JEL Classification: E24, E32 


\section{Introduction}

Recent analyses of longitudinal micro data have found that real wages are much more procyclical than they appear in aggregate time series data. ${ }^{1}$ Studies by Vroman (1977), Bils (1985), and Barlevy (2001) found that this is especially so for those who change employers. Numerous studies present reasonable explanations of why the wages of job changers are so procyclical. For example, Beaudry and DiNardo (1991) (hereafter BD) explain this based on implicit insurance between workers and firms. ${ }^{2}$ Workers who are forced to change jobs have no access to insurance, and their new wage rates are heavily dependent on the spot market condition, leading to higher fluctuations in the wage rate. In contrast, job stayers are protected against aggregate fluctuations by implicit insurance offered by employers, implying much smoother wage adjustments. Recently, Barlevy (2001), based on differences of unemployment risks, provides another alternative hypothesis that the strong wage procyclicality of job changers is due to compensating wages; that is, job changers receive higher wages in new jobs that pay compensating wages for subsequent losses of those jobs. ${ }^{3}$

However, recent empirical findings suggest that even the wages of job stayers are procyclical, although they are less so than those of movers. For example, on the basis of the Panel Study of Income Dynamics (PSID) for men in the period of 1968-69 to 86-87, Solon, Barsky, and Parker (henceforth SBP, 1994) found that a one percentage point reduction of the unemployment rate leads to a rise in the real wage rate of stayers by 1.2 percent. Similar estimates are found in Bowlus (1993), Shin (1994), and Devereux (2001).

The primary goal of this paper is to explain why real wages are procyclical

\footnotetext{
${ }^{1}$ Early studies by Raisian (1979) and Stockman (1983) point out that aggregated time series on real wages are counter-cyclically biased by their tendency to weigh low skilled workers more heavily in expansions than in recessions. Solon, Barsky, and Parker (1994) demonstrate rigorously how important this composition bias is. The latter study also presents a detailed summary of the time series evidence and a nice discussion of how this time series evidence has influenced macroeconomic theory.

2 See Azariadis (1975) and Baily (1974) among others for the theoretical underpinnings of the implicit contract theory.

3 An early work by Okun (1973) explains the large wage procyclicality among job changers based on
} 
among job stayers. In fact, despite the repeated findings, little study has been conducted to account for the fact. ${ }^{4}$ Since job stayers constitute a major fraction of the labor force, this is an important step in understanding the strong procyclicality of real wages. For example, estimates in Table IV of Solon et al. imply that $73 \%$ of the entire year-person observations and $95 \%$ of the total number of workers are classified as job stayers, which results in job stayers contributing from $66 \%$ to $85 \%$ of the estimated overall wage procyclicality (-.0138), respectively.

At first, the finding of substantial wage procyclicality among stayers seems at odds with the theoretical prediction of implicit contracts, as risk averse workers prefer complete wage smoothing to be shielded from productivity shocks. In terms of empirical conclusions, while SBP, among others, conclude that stayers' real wages are highly correlated with the contemporaneous unemployment rate, BD report that stayers' wages depend not on the contemporaneous unemployment rate but on the minimum unemployment rate observed since the beginning of the current job. This paper confronts the puzzle of the cyclicality of stayers' wages with new empirical evidence.

In theory, the prediction of wage smoothing in the conventional implicit contract theory hinges on a presumption that labor mobility is costly. Without mobility costs, however, wages need to be renegotiated upward when economic conditions improve sufficiently enough to prevent the worker from being bid away by other firms. Therefore, a (plausible) variation in the assumption would eliminate the prediction. As will be demonstrated in subsequent sections, once the conventional implicit contract theory is enriched to encompass free labor mobility across jobs, no further departures from the conventional model are needed to accord with the procyclicality of stayers' wages. In fact, BD also distinguish between implicit contract

\footnotetext{
inter-industry wage differentials and cyclical upgrading of labor.

4 Two papers are related with the current issue. First, using personnel records from the Ford and Byers companies, Solon, Whatley, and Stevens (1997) found some supporting evidence for the old hypothesis that a portion of firms' cyclical adjustment of labor costs is achieved not by changing the wages paid in particular jobs, but by changing the quality of labor assigned to those jobs. Second, Devereux (2001) found that the wage procyclicality within employer-employee matches is driven mostly by those who receive incentive-based pay, such as piece rate, overtime or commissions and that the hourly wage rate from hourly and salary workers is not responsive to the business cycle.
} 
models with and without mobility costs. With costly mobility, contract wages are negotiated once at the beginning of contract, and never change thereafter. Without mobility costs, however, wages are adjusted upward whenever the unemployment rate is at the historically minimum level since the start of the current job. In the empirical analyses, they regressed the wage rate on the unemployment rate at the starting point of the current tenure, the minimum unemployment rate since the start, and the current unemployment rate and found that only the minimum rate is significant. This provides a supporting evidence for the implicit contract model without mobility costs.

Nevertheless, we recognize that the BD's finding that wages do not depend on the current unemployment rate looks inconsistent with the evidence of procyclical stayers' wages, namely that real wages are strongly correlated with the current unemployment rate. This happened because of different methodologies adopted by the two sets of empirical studies. While empirical evidence of stayers' wage procyclicality focuses on the partial correlation of wages and the current labor market conditions, BD's test procedure is based on the link between wages and past as well as current labor market conditions. Our strategy is, therefore, to develop a test procedure, which is equivalent to the BD's test procedure but uses only the current unemployment rate, which will be explained in Section II.

By extending the sample period to 1974-1991, which includes one more business cycle than the sample period considered by SBP or BD, we replicate their results almost identically. For example, wages of stayers are found to be quite procyclical. BD's estimation results are also confirmed. Further we find that the wage adjustments of stayers are not uniform over the course of the entire job tenure. The wage adjustments are much higher when the unemployment rate is decreasing (the expansion period) than when the unemployment rate is increasing (the recession period). While most studies find asymmetric adjustments of nominal wages over the business cycle, our results indicate that this is also true for real wages. Most importantly, we find that wage adjustments are not uniform even in the expansion period but are actually concentrated on a special phase of the expansion period, called the period of renegotiation. This corresponds to the period when the unemployment rate dips below the historical minimum level observed since the start of the current job. On the contrary, wages are not adjusted much even when the unemployment rate decreases as 
long as it does not dip below the historical minimum. In short, stayers' substantial wage procyclicality as well as asymmetric adjustments of real wages is mostly accounted for by great wage adjustments during the re-negotiation period, as implied by the costless mobility version of implicit contracts suggested by BD. Our evidence clearly disputes an implicit contract model with costly mobility, because according to it, wages since the start of the current job should be acyclical, implying no correlation of wages and the current unemployment rates for the entire job tenure. Further our evidence also rejects the spot market model because it predicts that the correlation should be as great for the period when wages are not re-negotiated as for the renegotiation period.

This paper is organized as follows. Section II develops an alternative test procedure that is identical to the BD's test procedure but uses only the contemporaneous unemployment rate. Section III explains data used in our analyses. Section IV reports our main empirical results. We state our major conclusions in Section IV.

\section{Test Procedure}

Beaudry and DiNardo modified Harris and Holmstrom's (1982) theory to develop testable hypotheses of implicit contract models based on the link between wages and past labor market conditions. According to BD, if mobility is costless, contractual wage payments depend on the most favorable labor market condition observed since one has begun his/her job. This implies that the wage rate of an individual should depend on the minimum unemployment rate in his entire job tenure. On the contrary, if mobility is costly, contractual wage payments should be fixed for his entire job tenure. In this case the wage rate of an individual should depend upon the unemployment rate at the start of his/her current job. Finally, if wages are determined at the spot market, wages should depend on the current labor market conditions. In testing these hypotheses, BD augmented the standard Mincerian wage function by including the starting unemployment rate at the start of a job, the minimum unemployment rate observed since the start, and the current unemployment rate and examined the significance of these variables. More specifically the equation they 
estimated is:

$\ln W_{i t}=\alpha^{\prime} X_{i t}+\beta^{\prime} Z_{i}+\gamma_{1}$ Starting $_{i t}+\gamma_{2}$ Minimum $_{i t}+\gamma_{3}$ Current $_{i t}+v_{i t}$

where $W_{i t}$ is the ratio of the nominal wage of individual $i$ in year $\mathrm{t}$ to the Consumer Price Index $(\mathrm{CPI})$ in that year ${ }^{5}, X_{i t}$, a vector of time-varying individual characteristics such as experience, experience squared, tenure, dummies for industry, region, union status, marital status, and standard metropolitan statistical area (SMSA), and $Z_{i}$, a vector of individual-specific but time-invarient variables, which includes schooling, race, ability, and motivation. In addition, Starting $U_{i t}$ means the unemployment rate at the starting point of a job held at time t, Minimum $U_{i t}$, the minimum level of the unemployment rate observed between the starting point and time t, and Current $U_{i t}$, the current unemployment rate at time t. On the basis of the CPS and the PSID for the 1976-84 period, they estimate the Ordinary Least Squares (OLS) ${ }^{6}$ and the fixed-effects versions of equation (1) and conclude that the contract model with costless mobility describes the data best in the sense that the coefficient on Minimum $_{i t}$ is the greatest and statistically significant.

It is worth noting that their measures of the starting and the minimum unemployment rate are critically dependent on the duration of the current tenure. As emphasized by McDonald and Worswick (1999), an incorrect measurement of tenure is directly translated into an incorrect measurement of the minimum unemployment rate as well as the starting unemployment rate. As already pointed out by many researchers, tenure responses for the PSID and the National Longitudinal Survey (NLS) data are often inconsistent with calendar time. ${ }^{7}$ For example, Topel reports that, in the recorded tenure data for the $1968-83$ period of PSID white males, the year-to-year changes in job tenure range from -31 years to 7.5 years, and measured tenure declines

\footnotetext{
${ }^{5}$ We have also tested the GDP deflator and found little difference in the conclusion.

${ }^{6}$ Of course, when OLS is applied to equation (1), unobservable time-invarient variables are not controlled for.

${ }^{7}$ See Altonji and Shakotko (1987), Topel (1991), and Brown and Light (1992) among others.
} 
between years of a job in $3.8 \%$ of all cases. Our calculations show that, in the recorded tenure data for the 1975-91 period of PSID men, a little over $20 \%$ of all job spells have an initial reported tenure of 'more than 14 months.' All these figures suggest that (1) extreme care should be taken when using these error-ridden tenure variables and (2) other test procedures that are not critically dependent upon the duration of tenure are desirable.

To overcome these difficulties and, more importantly, to make our estimates comparable to estimates of the stayers' wage procycliclaity, we use the following alternative test procedure, which depends only on the contemporaneous unemployment rate. If, as concluded by $\mathrm{BD}$, an implicit contract with costless mobility governs the relationship between wages and past labor market conditions, wages should be adjusted to the contemporaneous unemployment rate whenever it goes below the historical minimum unemployment rate since the start of the current tenure. This is the period when re-negotiation takes place under the BD's theory. Therefore, once we select these years, the unemployment rate is monotonically decreasing over time within the current tenure. If the BD's conclusion is valid, the partial correlation of wages and contemporaneous unemployment rates would be high for this re-negotiation period, not for the rest of the period. On the other hand, if an implicit contract model with costly mobility is dominant, wages since the start of the current job are to be acyclical, implying no correlation of wages and contemporaneous unemployment rates. To put it conversely, the stayers' wage procyclicality itself rejects the hypothesis of an implicit contract with costly mobility. Finally, if wages are primarily determined at the standard spot market, then the correlation is expected to be as great for the period when wages are not re-negotiated as for the re-negotiation period.

Figure 1 illustrates these points. Suppose a person has a job as of 1991, which began in 1975. The BD model implies that, in each year for the 1976-79 period, wages are renegotiated as the unemployment rate is historically lowered. This happens because employers want to retain quality workers in cyclical upturns. Renegotiations do not take place as the unemployment rate goes up for the 1980-82 period. The BDspecific feature of implicit contracts is that re-negotiation does not take place even when the unemployment rate goes down as long as it is not lowered below the historical minimum level. This corresponds to the 1983-1987 period. In 1988, as the 
unemployment rate goes below the 1979 level, they revise the old 'contract' and do it again in 1989. As the labor market starts to deteriorate in 1990, wages are set at the 1989 level. Therefore, we consider three sample sub-periods: the entire sample period since the start of the current job, the sub-period when renegotiations take place (marked by large squares), and the sub-period when renegotiations do not take place. Then, for each sub-sample period, we estimate the correlation of real wages and contemporaneous unemployment rates. What we want to measure for each sub-sample period is the direction and the magnitude of composition-corrected and detrended mean wage changes associated with one unit change in the unemployment rate.

If wages are determined at the spot market, they are procyclical for the entire sample period since the start of a job, and wage adjustments are as great for the nonnegotiation period as for the re-negotiation period. If an implicit contract with costly mobility explains the data, wages will be noncyclical for the entire period since the start of a job. Finally, if an implicit contract with costless mobility describes the data, great upward wage adjustments will be made for the re-negotiation period, not for the other. Note that, if the last hypothesis is true, little wage adjustment takes place even for the period of falling unemployment as long as the rate does not reach the historical minimum.

Compared with the BD's, our test results are expected to be less sensitive to incorrect measurement of tenure. In our test procedure, incorrect measurement of tenure changes sub-sample periods slightly, with relatively little change in the mean wage adjustment within each sub-sample period. On the contrary, as previously mentioned, miss-measurement of tenure directly affects the starting and the minimum unemployment rates and, therefore, the corresponding coefficient estimates in the BD's specification.

To estimate wage cyclicality for stayers, we estimate the following augmented Mincerian wage function:

$\log W_{i t}=\gamma_{1}+\gamma_{2} t+\gamma_{3} t^{2}+\gamma_{4} E X_{i t}+\gamma_{5} E X_{i t}^{2}+\gamma_{6}^{\prime} Z_{i}+\gamma_{7} U R_{t}+\varepsilon_{i t}$

where $W_{i t}$ is again the ratio of the nominal wage of individual $i$ in year $t$ to the 
Consumer Price Index (CPI) in that year. Work experience $E X_{i t}$ is measured simply as the number of years since individual $i$ completed schooling. $Z_{i}$ is a vector of individual-specific, but time-independent, characteristics such as years of schooling, race, gender, ability, and motivation. $U R_{t}$ is the civilian unemployment rate in year $\mathrm{t}$ and is used as a cycle indicator. Both individuals' wages and the unemployment rate are expressed as deviations from quadratic time trends to focus on cyclical components of the two variables. Equation (2) is precisely the same specification used by SBP (1994) and many other longitudinal studies that investigate the cyclicality of real wages.

First-differencing equation (2) eliminates observable and unobservable characteristics, $Z_{i}$ :

$\Delta \log W_{i t}=\beta_{1}+\beta_{2} t+\beta_{3} E X_{i t}+\beta_{4} \Delta U R_{t}+\Delta \varepsilon_{i t}$

where $\beta_{1}=\gamma_{2}-\gamma_{3}+\gamma_{4}-\gamma_{5}, \quad \beta_{2}=2 \gamma_{3}$, and $\beta_{3}=2 \gamma_{5} . \quad \beta_{4}=\gamma_{7}$ is greater than, equal to, or less than zero as real wages are countercyclical, noncyclical, or procyclical.

Applying OLS to equation (3) produces inefficient estimates of $\beta$ coefficients. The differenced error term is cross-sectionally correlated because different workers share common time effects. Usual standard error estimators are biased downwardly by neglecting this effect. Moreover, the differenced error term may be serially correlated. To correct this, we apply a two-step estimation procedure that has been adopted by SBP (1994) and Shin (1994) among others. In the first step, we apply OLS to the regression of the logarithm of real wage growth on experience and a vector of year dummies. In the second step, we apply Generalized Least Squares (GLS) to the regression of the estimated year effects on a time trend and changes in the unemployment rate. As proved by Amemiya (1978), the two-step estimator that corrects for the non-sphericality of the second-stage error term is identical to the GLS estimator applied to the first-differenced equation in a single stage. We use this twostep method in estimating the cyclicality of stayers' wages.

For the purpose of estimating the correlation of real wages and contemporaneous unemployment rates for various sub-sample periods previously 
defined, we modify the above two step procedures. In the first step, we apply OLS to the regression of the logarithm of real wage growth on experience and vectors of year dummies for those sub-sample periods. In the second step, we apply a system of seemingly unrelated regressions with the coefficients on the intercept and the time trend restricted to be equal across equations. We correct for serial correlation within each equation. The unemployment coefficient of each equation represents the compositioncorrected and detrended mean wage change for each subsample period that the equation stands for associated with one unit change in the unemployment rate. For the sake of simplicity, estimated coefficients only on the unemployment rate are reported and discussed.

\section{Data}

We choose to use the PSID data for the following reasons. First, as noted by many researchers, tenure responses from survey-based data are often inconsistent with calendar time. Therefore, it is essential to make tenure series internally consistent at least within job duration using longitudinal surveys such as the PSID. Second, among existing longitudinal surveys, the PSID is preferable to the NLS mainly because the former represents the entire working age population better than the latter. Third, since BD and many existing empirical studies on stayers' wage procyclicality used the PSID, we use the same data set to avoid any possible outcome that may result from using different samples.

We do not use data prior to 1975 because tenure is recorded as a continuous measure only since 1975 . The tenure variable needs to be continuous because we need to know the starting point of a current job in order to divide the entire period of stay with the same employer into various sub-periods. Like most studies in this literature, we focus on men and exclude the self-employed because they are less likely to be affected by implicit contracts. To check the robustness of the results, we also test an extended data set with female heads included. However, we do not use data for wives because the self-employed can not be excluded until 1979.

Like BD, we work with the average hourly earnings variable, which is 
computed as the ratio of total earnings from all labor income sources for the preceding calendar year to annual hours worked in that year. Therefore, the data from the 197692 interviews include labor income and hour measures for 1975-91. ${ }^{8}$ This measure includes, in addition to basic wages and salaries, other sources of labor income such as overtime, bonus, and commission. We believe this average hourly earnings variable is preferable to basic wages and salaries because wages in implicit contracts, as suggested by 'implicit', are supposed to include every form of payments to workers. Following BD, we include in the sample respondents aged 21-64 who had positive earnings and who started their job after 1947. We exclude, however, the Survey of Economic Opportunity (SEO) sample from the analyses because, as indicated by BD, inclusion of the SEO sample makes little difference in the estimates and because existing estimates of real wage cyclicality are based only on the Survey Research Center (SRC) sample.

Numerous algorithms are developed by Altonji and Shakotko (1987), Topel (1991), Altonji and Williams (1992), Brown and Light (1992), and Altonji and Devereux (2000) to generate internally consistent tenure variables. Our method is very close to Altonji and Williams (1992) and Altonji and Devereux (2000). ${ }^{9}$ First, in defining job changers and/or stayers, employer tenure is compared with time elapsed since the previous interview. Accordingly, a job change is defined as having occurred if time with employer was less than elapsed time since the previous interview. The second step is to assign different weights on different observations within a job depending on how consistent the reported tenure values are with all of the other reported tenure values on the job. ${ }^{10}$ In the third step, we calculate a weighted average of reported tenure minus the time elapsed since the start of the job. This weighted average represents initial job tenure at the start of the current job. The fourth step is to determine the initial tenure level of a job. Like Altonji and Williams, we set the initial tenure level to one month whenever the estimated initial tenure is negative and discard

\footnotetext{
${ }^{8}$ We use 1974 data only for the purpose of obtaining data on 1974-75 wage changes.

9 We also tried the method adopted by Beaudry and DiNardo (1991) and the 'Partion P' method developed by Brown and Light (1992). Although different tenure-generating algorithms produce somewhat different tenure levels, the current conclusions are robust to these exercises. Our conclusions still preserve even when reported tenure variables are used.

${ }^{10}$ See Altonji and Williams (1992) for generating weights.
} 
the entire observations in a job spell when the estimated initial tenure is more than two years.

The fourth step is not applicable for jobs that were in progress as of 1975, the first year of our sample period, because we cannot determine the starting point of a job spell following the first step. For these 'left-censored' jobs, we apply the same procedure up to the third step. $^{11}$ In the fourth step, however, we determine the starting point of a job by simply using the estimated tenure as of 1975 and set to one month. Finally, starting from the first year of a job, we force tenure to increase exactly by the time elapsed between interviews. ${ }^{12}$

\section{Empirical findings}

Table 1 reports sample means of selected variables. In general, our sample means are somewhat different from those of BD (Table 1, p. 673, 1991) and very similar with those of Devereux (Table A1, p. 849, 2001). The latter two tables are based on PSID male heads for 1976-84 and 1971-91, respectively, in comparison with our sample of PSID male heads for the 1975-91 period. The differences between our sample means (or Devereux's) and BD's are largely attributed to the fact that, while BD included the SEO sample in their analyses, the current study and the Devereux's use only the SRC random sample.

Female heads constitute approximately $19.8 \%$ of the entire sample of heads, have lower wages, tenure, union membership rate, and proportion of marriage experience. There is no gender difference in the educational level. Therefore, the greater level of potential experience for women indicates that women are on average older than men in our sample, which in turn implies that the tenure gap between genders would be greater when the age difference between genders is controlled for. As will be demonstrated in subsequent subsections, however, our conclusions hold whether or not female heads are included in the sample.

\footnotetext{
11 At least three yearly observations are required to calculate the weighted average.

12 If the predicted starting point of a job is before 1968, the first year of PSID surveys, we assume an
} 
The average tenure on the current job, which is the most important variable because the starting and the minimum unemployment rates are critically dependent on the variable, is 8.79 years in our sample of male heads. This figure is somewhat greater than the BD's estimate (6.92 years with the SEO included), but smaller than Topel (9.98 years) and Devereux (2001: 10.11 years). The difference in the average tenure between our sample and the BD's makes us to check first if the BD's results hold even in our extended sample period which includes one more business cycle than the sample period considered by BD.

Table 2 reports estimated coefficients of various unemployment variables in equation (1), and compares them with the BD's. For the sake of simplicity, we present only the estimated coefficients of three unemployment measures, the starting, the minimum, and the contemporaneous unemployment rate. Comparing the numbers in the first two columns reveals that the BD's estimates are successfully replicated. Most importantly, for both the OLS and fixed-effects estimates, the minimum unemployment rate variable clearly dominates the other two variables in both studies. ${ }^{13}$ As minor differences, the estimated coefficient on the current unemployment rate is somewhat greater and statistically more significant in our study than in the BD's, and the fixedeffects estimates of the coefficient on the starting unemployment rate is positive and significant in our study, but insignificant in the BD's. ${ }^{14}$ As demonstrated in the fourth

equal interval of 12 months between interviews.

${ }^{13}$ A trend variable is not included in the BD's specification. At first, we suspected that the effects of the minimum unemployment rate on wages might be overstated due to this omission. The reason is as follows. For the 1947-84 period, the local minimum unemployment rate as well as the overall unemployment rate has been increasing. Therefore, the elapsed time since the minimum rate is negatively correlated with the minimum rate. Since wages grow over time, omitting the variable, the elapsed time since the minimum, would exaggerate the effect of the minimum rate. However, omitting the trend variable purposefully in our specification makes little difference due to the weak correlation of the minimum rate and the elapsed time since the minimum rate.

${ }^{14}$ When we restrict our sample to the 1976-84 period as in BD, the replication is almost exact in terms of magnitudes of estimated coefficients and their statistical significance. To summarize, as in the extended period, the minimum unemployment rate clearly dominates the other two variables in explaining the current wage rate. Moreover, as in $\mathrm{BD}$, although the estimated coefficient on the contemporaneous unemployment rate is virtually zero and imprecise from OLS, the estimate from the fixed-effects model is 
column, similar patterns are observed even when female heads are included in the sample. It is generally concluded that the contract model with costless mobility describes best the pattern of real wage movements over the cycle.

One can suspect that the large negative coefficient of the minimum unemployment rate may be due to nonlinearities in the effect of tenure. Especially if the effect of tenure on the wage rate is intensified when the unemployment rate is very low, the BD's results can be obtained. As an easy way to check this possibility, we include squared tenure as an additional regressor and re-estimate equation (1). The results are reported in the third and fifth columns of Table 2. The addition of the squared tenure variable has different effects depending on the econometrics model adopted. In OLS, the role of the minimum unemployment rate is dramatically reduced when squared tenure is included. For example, for the male heads, the estimated coefficient on the minimum rate is reduced from .0379 to .0129 in an absolute value. OLS estimates seem to suggest that the large coefficient on the minimum unemployment rate in the Beaudry and DiNardo's results was at least partly picking up nonlinearities in the effect of tenure. However, when we use the fixed-effects model, the effect becomes more or less negligible. For male heads, estimated coefficient is reduced in an absolute value from .0288 to .0269 . Therefore, once unobservable individual fixed effects are controlled for, the nonlinearities in the effect of tenure observed in the OLS estimates are no longer important in explaining the large negative effect of the minimum unemployment rate on wages. Overall, the BD's conclusion that the minimum unemployment rate is dominant in explaining current wages still preserves even in our extended sample with more recent years and female heads.

\section{A. Are real wages procyclical among job stayers?}

On the basis of equation (3), this subsection investigates if our extended sample produces substantial wage procyclicality among job stayers as well. The results are reported in Table 3. For the 1974-75 to 1990-91 period, the estimate turns

a small negative number and statistically significant. Finally, the coefficient on the starting unemployment rate is positive and significant from OLS, but insignificant from the fixed-effects model. 
out to be -.0093 for male heads, which is statistically significant at the 5 percent level. This implies that a one percentage point increase in the unemployment rate reduces stayers' real wages by .93 percent. When female heads are included in the sample, the estimate falls slightly to -.0088 . This reflects the fact that real wages are less procyclical for women than men. ${ }^{15}$

Comparison of our estimates with those of existing studies is in order. At first, our estimate of -.0093 seems to be smaller than the SBP's estimate in an absolute value. Using the PSID male heads for the 1968-69 to 1986-87 period, SBP estimated the stayers' wage procyclicality as -.0124 . The gap between our estimate and SBP's is explained by, among others, the following two factors. First of all, our sample period covers only part of 1970s, while the SBP's sample period is dominated by the 1970s. This tendency is mentioned by Kniesner and Goldsmith (1987, p. 1257) among others. Extending the sample to the 1970-71 to $1990-91$ period increases the estimate up to -.0107 with an estimated standard error of .0024. Second, SBP included selfemployed stayers in their sample, while our sample does not. As observed by Carrington, McCue, and Pierce (1996) among others, hourly wages are much more procyclical for the self-employed than for "wage and salary" workers. In fact, including self-employed stayers in the above extended sample period increases the estimated procycliclaity further to -.0121 with estimated standard error .0029 , which is virtually identical to the SBP's estimate. Our estimate of -.0107 for the 1970-71 to 1990-91 period is slightly greater than Devereux's estimate of -.0081, which is also based on the PSID male heads who are not self-employed for the same sample period and Shin's estimate of -.0095 , which is obtained from the NLS young men data for the 1966-67 to $1980-81$ period. $^{16}$ For the purpose of explaining stayers' wage procyclicality based on the subperiods defined in Section II, we stick to our estimate of -.0093 for the $1974-75$ to $1990-91$ period.

\footnotetext{
Exclusion of the SEO sample does not change any of the results, which is also noted by BD.

${ }^{15}$ For a similar finding, see Blank (1989), Tremblay (1990), and Solon, Barsky, and Parker (1994).

${ }^{16}$ On the basis of the NLSY data for the 1978-79 to 1996-97 period, we redo the above analyses and find that estimated wage procyclicality for stayers is -.0114 (s.e.=.0051) for males and -.0037 (s.e. $=.0043$ ) for females.
} 
B. Asymmetric effects of unemployment on wages

While Subsection A confirms the previously established finding that stayers' real wages are procyclical, we believe that the conventional approach has a major drawback. The conventional approach implicitly assumes that composition-corrected mean wage changes following a one point change in the unemployment rate are uniform during the entire period of a job tenure. However, as suggested in Section II, the two versions of the implicit contract models and the spot market model can be distinguished from each other by different degrees of wage adjustment for different subsample periods. However, before we further investigate this important implication of the models, we first examine if the wage adjustment is asymmetric in expansions and recessions. This is needed because there is a long tradition of Keynesian economics that asserts that the nominal wage is downwardly rigid, and there is a possibility that this is also true for the real wages of stayers. ${ }^{17}$ If this is so, stayers' real wages are upwardly adjusted in expansions and while stay put in recessions, leading to an estimate of overall procyclicality of stayers' wages. Upon accepting the asymmetry hypothesis, we further explore, in Subsection $\mathrm{C}$, if the greater wage adjustment is uniform during the entire boom period or solely accounted for by wage re-negotiation during the renegotiation period, as implied by the BD version of implicit contracts.

Before running regressions based on equation (3), we can do the simple following exercise to get a flavor of asymmetry. A real wage change for an individual (in logarithm) is divided by corresponding change in the unemployment rate. Then, the cycle-adjusted wage changes are averaged over individuals and years for each of the expansion and the recession period. These figures present roughly how wage adjustments to a unit change in the unemployment rate differ between expansions and recessions, although they are contaminated by differences in worker composition between the two sample periods and by secular components of wage growth. They are reported in the first two columns of Table 4. Two interesting patterns emerge. First,

${ }^{17}$ For recent empirical studies on nominal wage rigidity, see Mclaughlin (1994) and Card and Hyslop (1997). 
among male heads, wage growth in expansions (.0615) is much greater than wage reduction in recessions (-.0044). Second, standard deviation of wage changes is much greater in expansions (1.1706) than in recessions (.4686). These seem to suggest that there may be a downward wage rigidity even in the real term. The gap in mean wage changes between expansions and recessions becomes greater when female heads are included in the sample.

To see these points more clearly, Figure 2-1 through 2-4 display percent distributions of real wage changes in expansions and recessions, respectively. The first two figures correspond to male heads, while the latter two include female heads. Each cell width is .09 and tales of the distribution are massed at the extremes. The latter is to allow a better view of the intermediate categories. First, comparison of the first two figures reveals that the sample proportion of wage increases in expansions is greater than the proportion of wage decreases in recessions. In fact, the distribution is quite skewed to the right in expansions, but is more or less symmetric in recessions, implying that adjustments in wages are on average made in expansions only. Second, the sample proportion of 'relatively negligible wage changes,' that is, wage changes between -.045 and .045 , is $15.6 \%$ in expansions but $27.9 \%$ in recessions. These findings imply that, for a given change in unemployment, wage changes are more sizable in expansions than recessions. To put it another way, there seems to be downward wage rigidity even in the real term. The same patterns are observed even when female heads are included, as demonstrated in Figure 2-3 and Figure 2-4.

Now we investigate more formally the possibility of asymmetry based on equation (3) by including expansion and recession dummies and their interaction terms with the unemployment rate. The results are reported in the third and fourth columns of Table 4. Unlike the figures in the first and the second columns, these numbers represent mean wage changes for a unit change in the unemployment rate obtained by controlling for cyclical changes in worker composition and secular components of wages. For the sample of male heads, the estimated wage change in expansions is .0158 and that in recessions is .0029 , which clearly shows that there is strong evidence of asymmetrical wage adjustment. Corresponding numbers for the sample of heads are -.0165 and -.0024 in expansions and in recessions, respectively. In short, asymmetry of wage adjustment still preserves even when we focus on the cyclical components of 
wages and control for unobservable as well as observable individual characteristics. This finding is consistent with Hines et al. (2001)'s finding that the impact of a given unemployment change on real hourly wages is larger in expansions than in recessions. ${ }^{18}$ This asymmetric adjustment of real wages has an important implication that the spot market model does not explain the procyclicality of real wages for stayers because if the spot market model holds, real wage adjustment must be as great in recession as in expansions.

The finding of little real wages adjustment in recessions may surprise some because there is a common notion that wages are adjusted downward when the recession is severe, as in 1982. It should be noted, however, that the current conclusion is based only on job stayers. In fact, as noted by Barlevy (2001), a significant portion of the decrease in aggregate wages in recessions comes from wage losses among workers changing into lower-wage jobs. ${ }^{19}$

C. Why are wages so greatly adjusted during expansions?

In Section B, we have found that stayers' real wages are procyclical mainly due to significant wage adjustment in expansions. As noted in Section II, however, the implicit contract model with costless mobility can be entirely consistent with the findings in Subsection B as well as an overall procyclicality estimate of stayers' real wages. In addition, the implicit contract model with costless mobility holds another important implication that distinguishes it from the implicit contract model with costly mobility, the spot market model as well as the downward rigidity model. According to the implicit contract model with costless mobility, large upward wage adjustments are to be concentrated on the re-negotiation period, which is a sub-sample period of

\footnotetext{
${ }^{18}$ Their CPS-based analyses for the 1976-99 period report comparable estimates as -.0057 and -.0020 for expansions and recessions respectively with their respective standard errors .0022 and .0028 . For hours and total earnings, however, the impact of a change in unemployment rates is larger in recessions.

${ }^{19}$ Bleakley, Ferris, and Fuhrer (1999), among others, report that worker flows into unemployment and into employment are simultaneously high (particularly in manufacturing) in severe recessions as in 1982. Moreover, as concluded by Ruhm (1991) and Jacobson, LaLonde, and Sullivan (1993), displaced workers suffer from long-term earnings losses.
} 
expansions. In other words, wages are adjusted when and only when the unemployment rate records the historical minimum level. This peculiar pattern of real wage adjustments can create a fair degree of wage procyclicality for the entire period of staying with the same employer and, at the same time, some degree of asymmetry of wage adjustments. The purpose of this subsection is to examine if the implicit contract model with costless mobility explains all these empirical regularities in a unified way.

As emphasized, our test is implemented by dividing the entire period of job stay into various sub-sample periods. Before running regressions based on equation (3), we draw figures similar to Figure 2's. While Figure 2-1 through Figure 2-4 illustrate asymmetric wage adjustment in expansions and recessions, Figure 3-1 through 3-4 focus only on expansions and display percent distributions of real wage changes for the re-negotiation period and for the period of falling unemployment without renegotiation. The first two figures correspond to male heads, while the latter two include female heads in the sample. A glance at the figures is enough to see that cycle-adjusted wage adjustments are not uniform between the two sub-sample periods, as the two distributions look different. More specifically, the proportion of wage increase is much greater for the re-negotiation period than for the other period. In fact the distribution is quite skewed to the right for the renegotiation period, suggesting that the skewness in expansions in Figure 2.1 and 2.3 is due mostly to the skewness in the renegotiation period. Calculations show that, for male heads, the average wage increase in the renegotiation period (.073) is greater than that in the non-negotiation period during expansions (.056). Again, same patterns are preserved even in the sample of heads.

Now, we test more formally the three competing hypotheses proposed by BD in the alternative way described in Section II, which focuses on the relationship between wages and contemporaneous unemployment rates. We compute compositioncorrected and detrended mean wage changes for the three sub-sample periods: the renegotiation period, the period of falling unemployment without re-negotiation, and the recession period. The two-step estimation results are reported in Table 5. The most important finding is that wages are much more greatly adjusted during the renegotiation period than the other expansion period. For the sample of male heads, the estimated coefficient on the unemployment rate is -0.0264 , implying that a one 
percentage point reduction in the unemployment rate is associated with a 2.64 percent rise in real wages for the re-negotiation period. The estimate for the period of falling unemployment without re-negotiation is -.0076 percent, which is much smaller in absolute value and statistically insignificant. Finally in recessions, the estimate is .0031 , which implies that little wage adjustment is made. Hence, the substantial wage procyclicality of stayers' wages is mostly accounted for by the great upward wage adjustment during the re-negotiation period only. When female heads are included in the sample, the estimate for the period of falling unemployment without re-negotiation is -.0121. While this estimate is somewhat large, it is significantly smaller than that for the re-negotiation period (-.0361).

While the findings in Sub-section B suggest that there is strong evidence of asymmetry, this asymmetric adjustment in real wages is due to significant upward movement of real wages in the re-negotiation period. In fact, the estimates for the non-negotiation period during expansions are insignificant among male heads and marginally significant at the 10 percent level when female heads are included. These findings reject the possibility that the downward rigidity in real wages drives the asymmetric effects because, if the downward rigidity holds, then upward wage adjustment for the period of falling unemployment without re-negotiation should be as great as for the re-negotiation period. This peculiar pattern of real wages adjustment is consistent with the prediction of the implicit contract model with costless mobility suggested by BD.

Figures in the second and the fourth columns of Table 5 represent estimates obtained by including squared tenure as an additional regressor in equation (2). That corresponds to including the tenure variable itself as an additional regressor in equation (3). Inclusion of the variable also reduces the magnitude of upward wage adjustment slightly for the re-negotiation period, but the magnitude is minor. That is exactly the same conclusion with the fixed-effects estimates of the coefficient of the minimum unemployment rate in Table 2. To repeat, once individual-specific fixed-effects are fully controlled for, estimated upward wage adjustment for the re-negotiation period is not biased by not controlling for nonlinearity in the effect of tenure. 


\section{Conclusion}

Our major conclusions are as follows. First, as with previous studies, we find that real wages are substantially procyclical. This large magnitude of wage procyclicality among stayers itself rejects the hypothesis that wages are primarily determined by the labor market condition at the start of the current tenure. Evidence in the many current existing studies shows that wages are substantially adjusted from the start of a current job. Second, the effects of unemployment on wages are asymmetric in expansions and in recessions: most of the substantial procyclicality of stayers' wages is attributed to the expansionary period and little real wage adjustment is made during recessions. This finding rejects the spot market hypothesis because, under the spot market model, wage adjustments are to be symmetric across expansions and recessions in terms of direction and magnitude. Third, asymmetric adjustments of real wages mostly occur during the re-negotiation period, and therefore, this adjustment solely explains procyclicality of real wages for stayers. Therefore, the substantial wage procyclicality and the peculiar pattern of asymmetric wage adjustments for job stayers are consistent with an implicit contract theory with costless mobility, as developed and concluded by Beaudry and DiNardo (1991).

Our findings imply that, for an 'average' stayer, real wages are a convex function of the unemployment rate, that is, wages tend to be adjusted greatly when the unemployment rate is relatively low, and little wage adjustment occurs during the period of high unemployment. This happens because the falling unemployment rate increases the probability of recording the best labor market condition since the start of the current job, which in turn makes the chance of re-negotiation greater. Previous research analyzing the wage-unemployment relationship either presumes linearity or, as in the Blanchflower-Oswald-type wage curve, explores how wages are nonlinearly dependent upon the current unemployment rate assuming that wages are determined at the spot market. The current study departs from those studies by examining how wages of a given worker respond nonlinearly at different phases of the business cycle and why wages of different individuals respond differently to the same unemployment change. In this sense, our paper goes beyond simply exploring functional forms of the wage-unemployment relationship and uncovers sources of the nonlinearity. 


\section{References}

Altonji, Joseph G., and Paul J. Devereux. 2000. "The Extent and Consequences of Downward Nominal Wage Rigidity." Research in Labor Economics, Vol. 19, pp. 383431

Altonji, Joseph, and Robert Shakotko. 1987. "Do Wages Rise with Job Seniority?" Review of Economic Studies, Vol. 54, pp. 437-59.

Altonji, Joseph G., and Nicolas Williams. 1992. "Do Wages Rise with Job Seniority? A Reassessment.” National Bureau of Economic Research Working Paper No. 6010.

Azariadis, Costas. 1975. "Implicit Contracts and Unemployment Equilibria." Journal of Political Economy, Vol. 83, pp. 1183-1202.

Baily, Martin N. 1974. "Wages and Employment under Uncertain Demand." Review of Economic Studies, Vol. 41, pp. 37-50.

Barlevy, Gadi. 2001. "Why Are the Wages of Job Changers So Procyclical?" Journal of Labor Economics, Vol. 19, pp.

Beaudry, Paul, and John DiNardo. 1991. "The Effect of Implicit Contracts on the Movement of Wages over the Business Cycle: Evidenc from Micro Data." Journal of Political Economy, Vol. 99, pp. 665-88.

Bils, Mark J. 1985. "Real Wages over the Business Cycle: Evidence from Panel Data." Journal of Political Economy, Vol. 93, pp. 666-89.

Blanchflower, David G., and Andrew J. Oswald. 1994. The Wage Cuve. MIT Press, Cambridge, MA.

Blank, Rebecca M. 1989. "Disaggregating the Effect of the Business Cycle on the Distribution of Income." Economica, Vol. 56, pp. 141-63.

Bleakley, Hoyt, Ann E. Ferris, and Jeffrey C. Fuhrer. 1999. "New Data on Worker Flows during Business Cycles.” New England Economic Review, pp. 49-76.

Bowlus, Audra. 1993. "Matching Workers and Jobs: Cyclical Fluctuations in Match 
Quality." Journal of Labor Economics, Vol. 13, pp. 335-50.

Brown, James N., and Audrey Light. 1992. "Interpreting Panel Data on Job Tenure." Journal of Labor Economics, Vol. 10, pp. 219-57.

Card, D. 1995. "The Wage Curve: A Review." Journal of Economic Literature, Vol. 33, pp. 785-99.

Card, D. and D. Hyslop. 1997. "Does Inflation 'Grease the Wheels of the Labour Market'?" In Reducing Inflation: Motivation and Strategy, edited by C.D. Romer and D.H. Romer, 71-114. Chicago: University of Chicago Press.

Carrington, William J., Kristin McCue, and Brooks Pierce. 1996. "The Role of Employer/Employee Interactions In Labor Market Cycles: Evidence from the SelfEmployed." Journal of Labor Economics, Vol. 14, pp. 571-602.

Devereux, Paul J. 2001. "The Cyclicality of Real Wages Within Employer-Employee Matches." Industrial and Labor Relations Review, Vol. 54, pp. 835-50.

Harris, Milton, and Bengt Holmstrom. 1982. "A Theory of Wage Dynamics." Review of Economic Studies, Vol. 49, pp. 315-33.

Hines, JamesR., Hilary Hoynes, and Alan B. Krueger. 2001. "Another Look At Whether A Rising Tide Lifts All Boats." National Bureau of Economic Research, working paper No. 8412.

Jacobson, Louis S., Rebert J. LaLonde, and Daniel G. Sullivan. 1993. "Earnings Losses of Displaced Workers.” American Economic Review, Vol. 83, pp. 685-709.

Kniesner, Thomas J., and Arthur H. Goldsmith. 1987. "A Survey of Alternative Models of the Aggregate U.S. Labor Market." Journal of Economic Literature, Vol. 25, pp. 1241-80.

McDonald, James T., and Christopher Worswick. 1999. "Wages, Implicit Contracts, and the Business Cycle: Evidence from Canadian Micro Data." Journal of Political Economy, Comments, Vol. 107, pp. 884-92.

McLaughlin, K.J. 1994. “Rigid Wages?” Journal of Monetary Economics 34 (3): 383- 
414.

McLaughlin, Kenneth J. and Mark Bils. 2001. "Interindustry Mobility and the Cyclical Upgrading of Labor," Journal of Labor Economics, Vol 19, no. 1, pp94-135.

Okun, Arthur. 1973. "Upward Mobility in a High-Pressure Economy." Brookings Papers on Economic Activity 1, 207-52.

Raisian, John. 1979. "Cyclical Patterns in Weeks and Wages.” Economic Inquiry, Vol. 17, pp. 475-95.

Roy, A.D.. 1951. "Some thoughts on the Distribution of Earnings," Oxford Economic Papers, Vol. 3, pp.135-46.

Ruhm, Christopher J.. 1991. "Are Workers Permanently Scarred by Job Displacements?" American Economic Review, Vol. 81, pp. 319-23.

Shin, Donggyun. 1994. "Cyclicality of Real Wages Among Young Men." Economics Letters, Vol. 46, pp. 137-42.

Solon, Gary, Robert Barsky, and Jonathan A. Parker. 1994. "Measuring the Cyclicality of Real Wages: How Important Is Composition Bias?" Quarterly Journal of Economics, Vol. 109, pp. 1-25.

Solon, Gary, Warren Whatley, and Ann H. Stevens. 1997. "Wage Changes and Intrafirm Job Mobility over the Business Cycle: Two Case Studies." Industrial and Labor Relations Review, Vol. 50, pp. 402-15.

Topel, Robert. 1991. "Specific Capital, Mobility, and Wages: Wages Rise with Job Seniority." Journal of Political Economy, Vol. 99, pp. 145-76.

Tremblay, Carol H. 1990. "Wage Patterns of Women over the Business Cycle." Quarterly Review of Economics and Business, Vol. 30, pp. 90-101.

Vroman, Wayne. 1977, "Worker Upgrading and the Business Cycle." Brookings Papers on Economic Activity 1, pp. 1229-50. 
Figure 1

Timing of Re-negotiation

Re-negotiations take place whenever the unemployment rate reaches a historical minimum level from the start of a job.

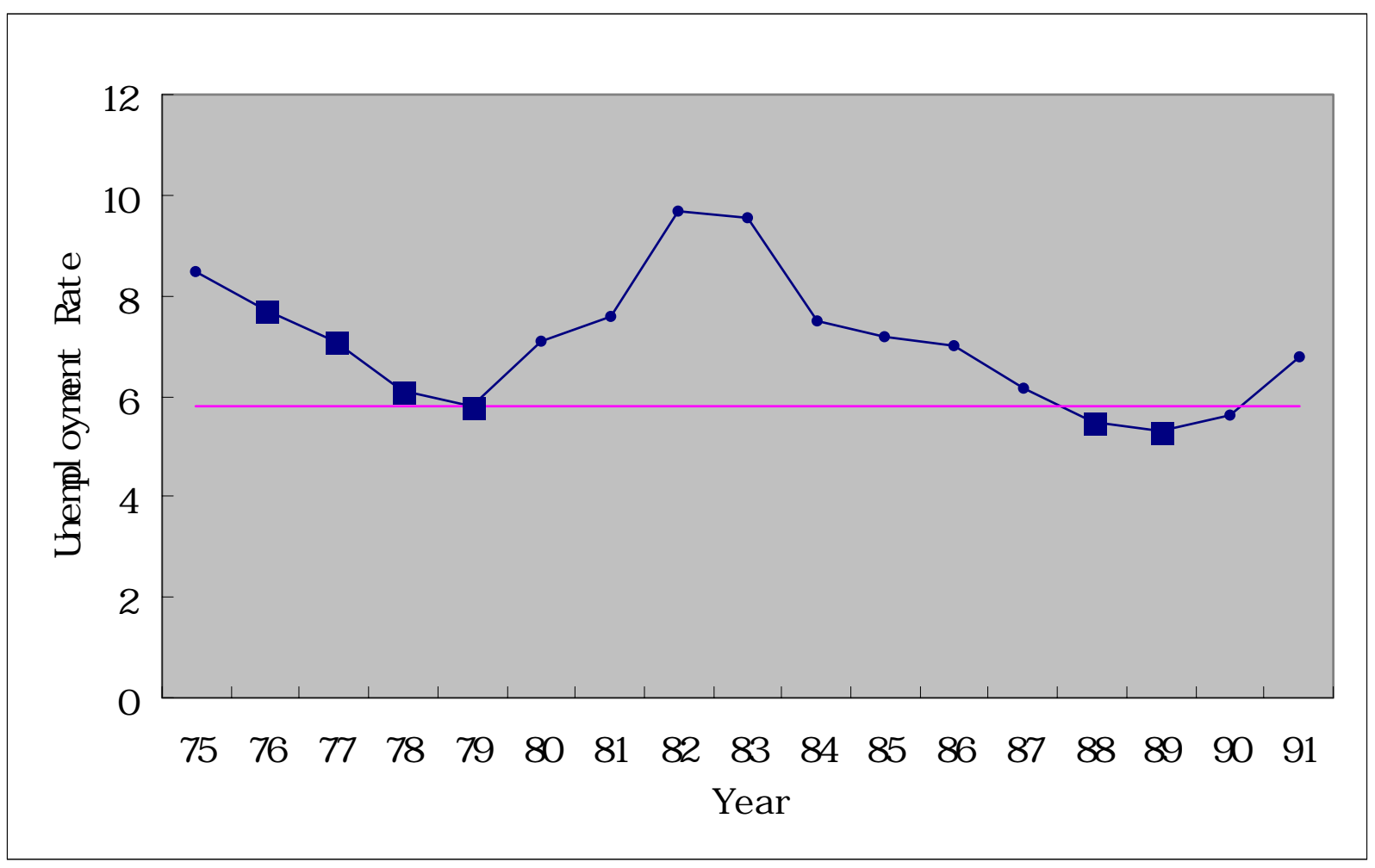


Figure 2-1

Distribution of Real Wage Changes in Expansions: Male Heads, 1974-75 to 1990-91

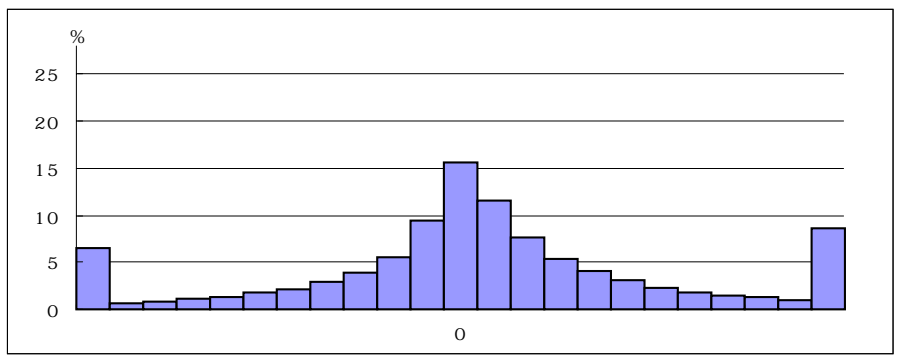

Figure 2-2

Distribution of Real Wage Changes in Recessions: Male Heads, 1974-75 to 1990-91

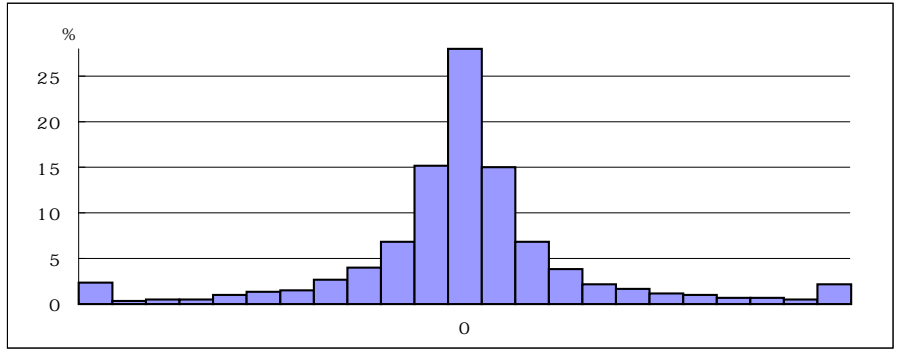

Figure 2-3

Distribution of Real Wage Changes in Expansions: Heads, 1974-75 to 1990-91

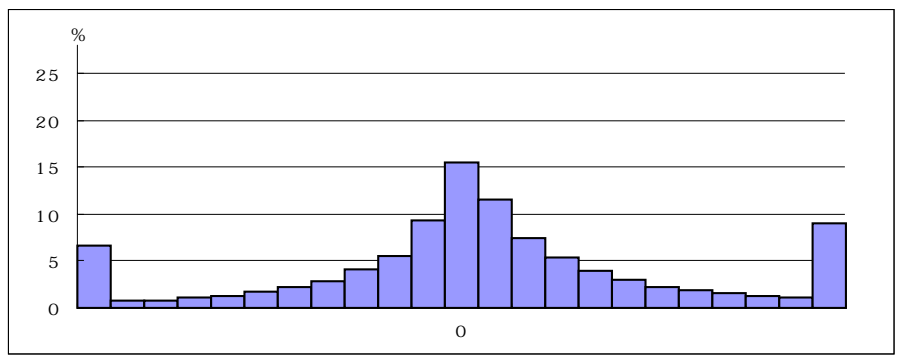

Figure 2-4

Distribution of Real Wage Changes in Recessions: Heads, 1974-75 to 1990-91

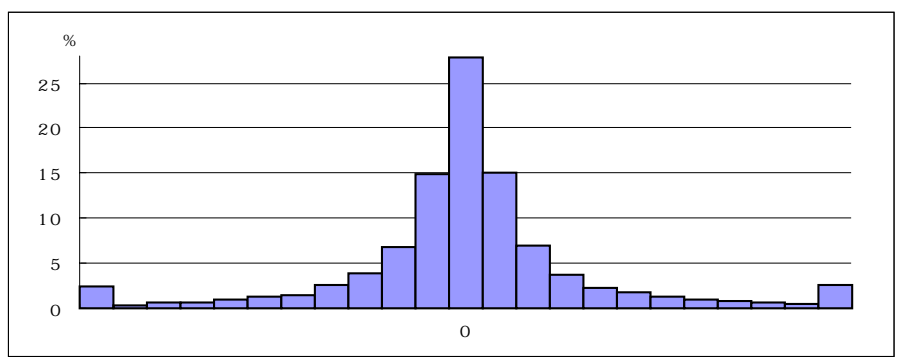


Figure 3-1

Distribution of Real Wage Changes for the re-negotiation period: Male Heads

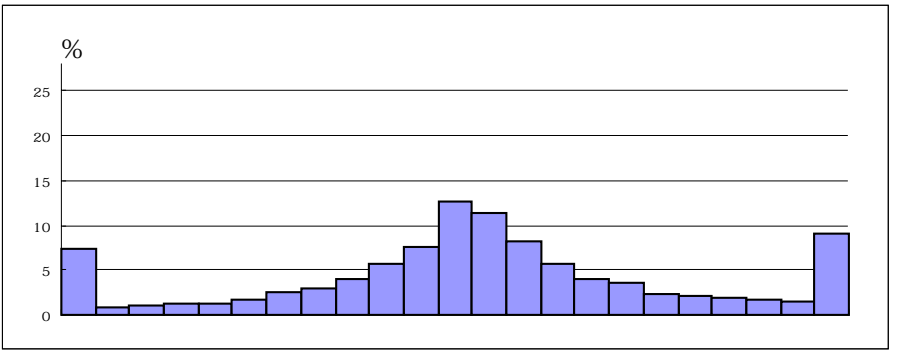

Figure 3-2

Distribution of Real Wage Changes for the period of expansion without re-negotiation: Male Heads

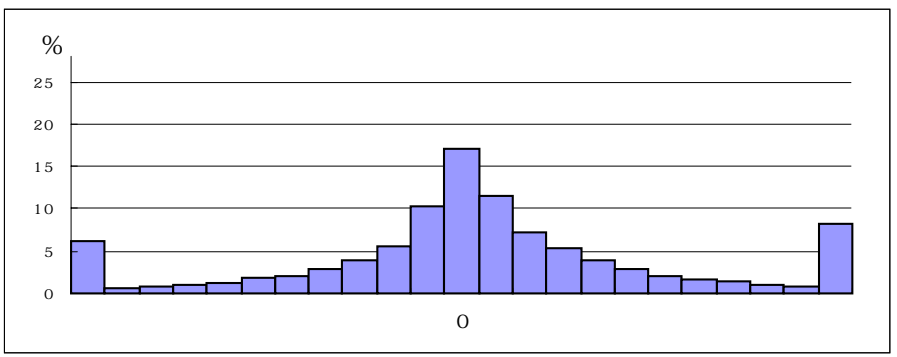

Figure 3-3

Distribution of Real Wage Changes for the re-negotiation period: Heads

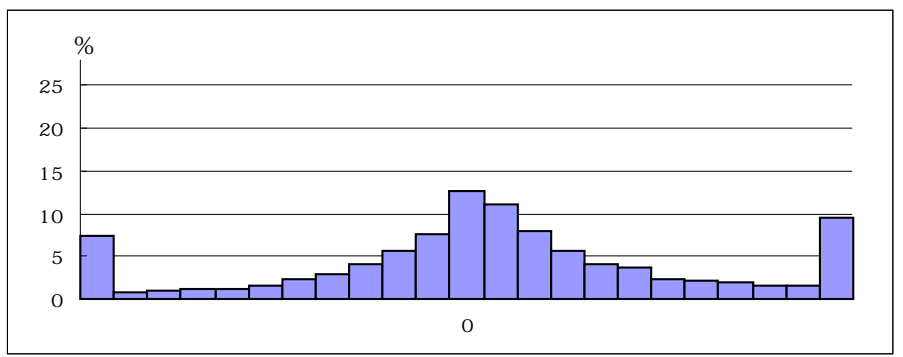

Figure 3-4

Distribution of Real Wage Changes for the period of expansion without re-negotiation: Heads

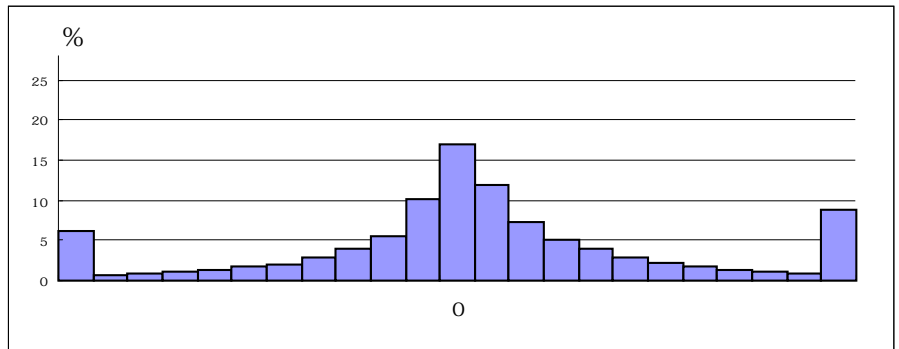


Table 1

Summary Statistics

Panel Study of Income Dynamics: 1975 to 1991 (units: dollar, year, percent)

\begin{tabular}{|c|c|c|}
\hline $\begin{array}{c}\text { Average log hourly earnings (1996 } \\
\text { dollars) }\end{array}$ & Male Heads & Female Heads \\
\hline Education & 2.36 & 13.12 \\
\hline Tenure & 13.13 & 8.40 \\
\hline Age-education -6 & 8.79 & 18.22 \\
\hline Union & 18.09 & 22.72 \\
\hline Nonwhite & 23.99 & 10.19 \\
\hline SMSA & 8.65 & 58.80 \\
\hline Ever married & 57.06 & 87.22 \\
\hline No. of observations & 92.24 & 5,691 \\
\hline
\end{tabular}

Table 2

Effects of Past and Current Unemployment Rates on Wages

Panel Study of Income Dynamics: 1975 to 1991

\begin{tabular}{|c|c|c|c|c|c|c|}
\hline \multirow{3}{*}{ Model } & \multirow{3}{*}{$\begin{array}{l}\text { Unemploym } \\
\text { ent } \\
\text { Measures }\end{array}$} & \multirow{3}{*}{$\begin{array}{c}\text { Beaudry \& } \\
\text { DiNardo } \\
\text { Male } \\
\text { Heads, SEO } \\
\text { included } \\
\text { 1976-84 }\end{array}$} & \multicolumn{4}{|c|}{$\begin{array}{c}\text { Current Study } \\
\text { SEO excluded } \\
1975-91\end{array}$} \\
\hline & & & \multicolumn{2}{|c|}{ Male Heads } & \multicolumn{2}{|c|}{ Heads } \\
\hline & & & $\begin{array}{l}\text { without } \\
\text { tenure }^{2}\end{array}$ & $\begin{array}{c}\text { with } \\
\text { tenure }^{2}\end{array}$ & $\begin{array}{l}\text { without } \\
\text { tenure }^{2}\end{array}$ & $\begin{array}{c}\text { with } \\
\text { tenure }^{2}\end{array}$ \\
\hline \multirow{3}{*}{$\mathrm{OLS}^{\mathrm{a}}$} & Current U & $\begin{array}{l}-.000 \\
(.002)\end{array}$ & $\begin{array}{c}-.0093 * * * \\
(.0028)\end{array}$ & $\begin{array}{l}-.0138 * * * \\
(.0028)\end{array}$ & $\begin{array}{c}-.0078 * * * \\
(.0026)\end{array}$ & $\begin{array}{c}-.0117 * * * \\
(.0027)\end{array}$ \\
\hline & Start U & $\begin{array}{c}.013 * * * \\
(.006)\end{array}$ & $\begin{array}{c}.0193 * * * \\
(.0031)\end{array}$ & $\begin{array}{c}.0130 * * * \\
(.0031)\end{array}$ & $\begin{array}{c}.0195 * * * \\
(.0029)\end{array}$ & $\begin{array}{c}.0141 * * * \\
(.0029)\end{array}$ \\
\hline & Min U & $\begin{array}{c}-.059 * * * \\
(.006)\end{array}$ & $\begin{array}{c}-.0379 * * * \\
(.0052)\end{array}$ & $\begin{array}{c}-.0129 * * \\
(.0056)\end{array}$ & $\begin{array}{c}-.0366 * * * \\
(.0049) \\
\end{array}$ & $\begin{array}{l}-.0154 * * * \\
(.0052)\end{array}$ \\
\hline \multirow{3}{*}{$\begin{array}{l}\text { Fixed- } \\
\text { effects }\end{array}$} & Current U & $\begin{array}{c}-.007 * * * \\
(.0025)\end{array}$ & $\begin{array}{c}-.0123 * * * \\
(.0016)\end{array}$ & $\begin{array}{c}-.0127 * * * \\
(.0017)\end{array}$ & $\begin{array}{c}-.0111 * * * \\
(.0015)\end{array}$ & $\begin{array}{c}-.0118 * * * \\
(.0016)\end{array}$ \\
\hline & Start U & $\begin{array}{l}-.006 \\
(.007)\end{array}$ & $\begin{array}{c}.0122 * * * \\
(.0029)\end{array}$ & $\begin{array}{c}.0117 * * * \\
(.0030)\end{array}$ & $\begin{array}{c}.0129 * * * \\
(.0027)\end{array}$ & $\begin{array}{c}.0113 * * * \\
(.0028)\end{array}$ \\
\hline & Min U & $\begin{array}{c}-.029 * * * \\
(.008)\end{array}$ & $\begin{array}{c}-.0288 * * * \\
(.0039)\end{array}$ & $\begin{array}{c}-.0269 * * * \\
(.0042)\end{array}$ & $\begin{array}{c}-.0285 * * * \\
(.0036)\end{array}$ & $\begin{array}{c}-.0245 * * * \\
(.0039)\end{array}$ \\
\hline \multicolumn{2}{|c|}{ No. of Observations } & & \multicolumn{2}{|c|}{28,707} & \multicolumn{2}{|c|}{34,398} \\
\hline
\end{tabular}

${ }^{a}$ In addition to the above three unemployment measures, the following explanatory variables are included: a quadratic time trend, experience, experience squared, schooling, tenure, and dummies for industry, region, race, union status, marital status, standard metropolitan statistical area. Estimated standard errors are in parentheses.

$* *, * * *=$ significant at the $5 \%$ and $1 \%$ level, respectively. 
Table 3

Estimates of Real Wage Cyclicality for Employer Stayers ${ }^{\mathrm{a}}$

Panel Study of Income Dynamics: 1974-75 to 1990-91

\begin{tabular}{|c|c|c|}
\hline & Male Heads & Heads \\
\hline Estimates & $\begin{array}{c}. .0093^{* *} \\
(.0040)\end{array}$ & $\begin{array}{c}-.0088^{* *} \\
(.0041)\end{array}$ \\
\hline $\begin{array}{c}\text { No. of differenced year-person observations } \\
\text { in the first step }\end{array}$ & 22,019 & 25,891 \\
\hline
\end{tabular}

${ }^{a}$ Estimates are based on the two-step method described in Section II. Estimated standard errors are in parentheses.

** Significant at the 5 percent level.

Table 4

Asymmetric Effects of Unemployment on Wages in Expansions and Recessions ${ }^{\mathrm{a}}$

Panel Study of Income Dynamics: $1974-75$ to $1990-91$

\begin{tabular}{|c|c|c|c|c|}
\hline \multirow{2}{*}{} & \multicolumn{2}{|c|}{ Mean Wage Change } & \multicolumn{2}{c|}{$\begin{array}{c}\text { Composition Corrected and } \\
\text { Detrended Mean Wage Change }\end{array}$} \\
\cline { 2 - 5 } & Male Heads & Heads & Male Heads & Heads \\
\hline \multirow{2}{*}{ Expansion } & .0615 & .0765 & -.0158 & -.0165 \\
& {$[1.1706]$} & {$[1.1956]$} & $(.0071)$ & $(.0094)$ \\
\hline \multirow{2}{*}{ Recession } & -.0044 & .0033 & .0029 & -.0024 \\
& {$[.4686]$} & {$[.4992]$} & $(.0049)$ & $(.0060)$ \\
\hline
\end{tabular}

${ }^{\text {a }}$ Estimates are based on the two-step method described in Section II. Numbers in brackets and parentheses are sample standard deviations of individuals' wage changes and estimated standard errors, respectively.

Table 5

Explaining Stayers' Wage Procyclicality ${ }^{\mathrm{a}}$

Panel Study of Income Dynamics: 1974-75 to 1990-91

\begin{tabular}{|c|c|c|c|c|}
\hline \multirow[b]{2}{*}{ Sub-sample Periods } & \multicolumn{2}{|c|}{ Male Heads } & \multicolumn{2}{|c|}{ Heads } \\
\hline & $\begin{array}{l}\text { without } \\
\text { tenure }^{2}\end{array}$ & $\begin{array}{c}\text { with } \\
\text { tenure }^{2}\end{array}$ & $\begin{array}{l}\text { without } \\
\text { tenure }^{2}\end{array}$ & $\begin{array}{c}\text { with } \\
\text { tenure }^{2}\end{array}$ \\
\hline Expansion: Re-negotiation & $\begin{array}{c}-.0264 * * \\
(.0076)\end{array}$ & $\begin{array}{c}-.0243 * * \\
(.0075)\end{array}$ & $\begin{array}{c}-.0361 * * \\
(.0103)\end{array}$ & $\begin{array}{c}-.0343^{* *} \\
(.0103)\end{array}$ \\
\hline Expansion: Non-negotiation & $\begin{array}{l}-.0076 \\
(.0034)\end{array}$ & $\begin{array}{l}-.0073 \\
(.0033)\end{array}$ & $\begin{array}{l}-.0121 * \\
(.0040)\end{array}$ & $\begin{array}{c}-.0122 * \\
(.0041)\end{array}$ \\
\hline Recession & $\begin{array}{l}-.0031 \\
(.0034)\end{array}$ & $\begin{array}{l}-.0033 \\
(.0035)\end{array}$ & $\begin{array}{c}.0087 \\
(.0051)\end{array}$ & $\begin{array}{c}.0079 \\
(.0052)\end{array}$ \\
\hline
\end{tabular}

${ }^{a}$ Estimates are based on the two-step method described in Section II. Estimated standard errors are in parentheses.

$*, * *=$ significant at the $10 \%$ and $5 \%$ level, respectively. 